Jurnal Ilmu Pertanian Agonitas Vol. 1 No.2 Edisi Oktober 2019

\title{
PENGARUH BERBAGAI JENIS MEDIA TANAM DAN NUTRISI TERHADAP PERTUMBUHAN DAN PRODUKSI TANAMAN PARE (Momordica charantia L.) DENGAN HIDROPONIK SISTEM WICK
}

\section{(The Effect Of Various Types Of Plants And Nutrition On Growth And Production Of Pare Plant (Momordica Charantia L.) With Hydroponic Wick System)}

\author{
Oksilia*), Silahuddin Alby1), Delvi Kristiani Gea \\ 1)Dosen Fakultas Pertanian Universitas Tamansiswa Palembang \\ *)Penulis untuk korespondensi: : oksilia@gmail.com
}

\begin{abstract}
ABSTRAK
Penelitian ini bertujuan untuk mengetahui pengaruh jenis media tanam dan jenis nutrisi yang berbeda terhadap pertumbuhan dan produksi tanaman pare (Momordica charantia L.). Penelitian ini menggunakan Rancangan Acak Lengkap (RAL) factorial dan menggunakan 2 faktor. Faktor yang pertama adalah jenis media tanam yaitu rockwool(M1), arang sekam (M2) dan cocopeat (M3). Sedangkan faktor yang kedua adalah jenis nutrisi larutan yaitu AB Mix (K1), NPK (K2), pupuk organik cair (K3) dan pupuk majemuk lengkap (K4). Kombinasi perlakuan jenis media tanam dan jenis nutrisi yang menunjukkan hasil terbaik sampai produksi adalah $\mathrm{M}_{2} \mathrm{~K}_{1}$ (arang sekam dan nutrisi $A B$ Mix) karena arang sekam memiliki kandungan karbon yang tinggi sehingga selalu gembur dan memiliki karakteristik yang ringan, kasar dan sirkulasi udara tinggi karena banyak pori, kapasitas menahan air yang baik serta warnanya yang hitam dapat mengabsorbsi sinar matahari sedangkan nutrisi $A B$ Mix memiliki komposisi hara seimbang yaitu kandungan makro dan mikro yang dibutuhkan tanaman.
\end{abstract}

Kata kunci: pare, media tanam, nutrisi

\section{ABSTRACT}

This study aimed to determine the effect of different types of planting media and types of nutrients on the growth and production of bitter melon (Momordica charantia L.). This research used factorial completely randomized design (RAL) and uses 2 factors. The first factor was the type of planting media, namely rockwool (M1), husk charcoal (M2) and cocopeat (M3). While the second factor was the type of nutrient solution, namely $A B$ Mix (K1), NPK (K2), liquid organic fertilizer (K3) and complete compound fertilizer (K4). The combination of the treatment type of planting media and the type of nutrition that showed the best results until production was M2K1 (husk charcoal and AB Mix nutrition) because the husk charcoal has a high carbon content so it is always loose and has mild, rough and high air circulation characteristics due to many pores, good water holding capacity and its black color can absorb sunlight while AB Mix nutrition has a balanced nutrient composition that is macro and micro content needed by plants.

Keyword: Momordica charantia L, planting media, nutrition

\section{PENDAHULUAN}

\section{A. Latar Belakang}

Tanaman pare (Momordica charantia

L.) merupakan tanaman herba berumur setahun yang tumbuhnya merambat. Buahnya berbentuk lonjong dan berwarna hijau dengan permukaan kulit buah terdapat bintil-bintil. Batangnya kecil dan panjang, daunnya berbentuk menjari dengan permukaan atas hijau 
tua dan permukaan bawah hijau muda atau hijau kekuning-kuningan. Tanaman pare bukanlah tanaman asli Indonesia, melainkan berasal dari India bagian barat, yakni Assam dan Burma, namun tidak diketahui sejak kapan tanaman ini masuk ke wilayah Indonesia. Tanaman pare sudah dibudidayakan di berbagai daerah di wilayah nusantara, umumnya dilakukan sebagai usaha sampingan yang ditanam di lahan pekarangan, tegalan atau di sawah bekas penanaman padi pada musim kemarau.

Teknik budidaya pare yang mudah dan tidak tergantung pada musim menyebabkan tanaman ini tersedia setiap saat. Beberapa jenis pare belum dibudidayakan secara komersial sehingga hasilnya pun belum optimal. Tanaman pare banyak digemari masyarakat sebagai sayuran. Setiap $100 \mathrm{~g}$ buah pare memiliki kandungan gizi antara lain, protein $0,90 \mathrm{~g}$, lemak $0,04 \mathrm{~g}$, karbohidrat $4,60 \mathrm{~g}$, kalsium 32,00 $\mathrm{mg}$, fosfat $32,00 \mathrm{mg}$, vitamin $\mathrm{A}, \mathrm{B}$, dan $\mathrm{C}$, dan bagian yang dapat dimakan $77 \%$ (Bastari et al., 2017).

Rasa pahit buah pare disebabkan oleh kandungan glikosida kukurbitasin yang dapat digunakan sebagai obat herba. Pare memiliki rasa pahit terutama pada daun dan buahnya, hal ini disebabkan karena kandungan zat sejenis glikosida yang disebut momordicin dan charantin. Buah pare memiliki manfaat yang sangat banyak seperti mengobati beberapa penyakit seperti luka, demam, campak, hepatitis, gangguan pernapasan, mencegah diabetes (Phytonutrient dan Polipeptida- $P$ ) yang berfungsi sebagai insulin guna menurunkan kadar gula darah dalam tubuh), melindungi kehamilan (memiliki kadar folat yang sangat baik), sebagai antioksidan, mencegah radikal bebas, mengobati jerawat, mencegah kanker, menurunkan berat badan, dan lain sebagainya (Hernawati, 2011).
Tanaman pare mempunyai daya adaptasi tumbuh yang cukup tinggi sehingga dapat menyesuaikan diri terhadap iklim yang berbeda baik suhu dan curah hujan yang tinggi, dapat hijau sepanjang tahun dan tidak tergantung musim. Budidaya tanaman pare secara luas masih banyak mengalami kendala, diantaranya adalah kesuburan tanah atau hara tanaman yang rendah. Kendala lain yang dihadapi adalah produksi pare di Indonesia masih sangat rendah sehingga pemerintah tidak memasukkan komoditi ini kedalam prioritas pengembangan hortikultura (Arif, 2010). Salah satu usaha untuk meningkatkan produksi tanaman pare, belakangan ini telah dikembangkan suatu teknologi pertanian yang memproduksi tanaman sayuran sehat, rendah zat kimia berbahaya, serta dapat diusahakan di berbagai tempat bahkan di masyarakat perkotaan sekalipun, yaitu hidroponik.

Hidroponik merupakan sistem budidaya tanaman tanpa menggunakan tanah sebagai media tumbuh tanaman dengan tambahan nutrisi untuk pertumbuhan. Keuntungan bercocok tanam sistem hidroponik yaitu kebersihan tanaman lebih mudah dijaga, tidak perlu melakukan pengolahan lahan dan pengendalian gulma, media tanam steril, penggunaan air dan pupuk sangat efisien, tanaman dapat dibudidayakan terus tanpa tergantung musim, dapat dilakukan pada lahan yang sempit, serta terlindung dari hujan dan matahari langsung (Silvina dan Syafrinal, 2008).

Media tanam dan nutrisi merupakan unsur utama dalam budidaya secara hidroponik. Media tanam dalam budidaya secara hidroponik berfungsi sebagai tempat akar untuk berpijak, membantu tanaman tetap tegak, menjaga kelembaban dan menyimpan air atau nutrisi yang dibutuhkan oleh tanaman (Safriani, 2018). Media tanam hidroponik dapat berupa cocopeat, serbuk gergaji, arang sekam, rockwool dan lainlain. Media tanam organik seperti cocopeat dan 
serbuk gergaji memiliki daya serap air yang tinggi, harganya terjangkau dan banyak ditemukan di sekitar kita. Rockwool mampu menahan air dan udara dalam jumlah yang baik untuk mendukung pertumbuhan akar (Syariefa, 2014).

Nutrisi merupakan faktor penting yang harus diperhatikan dalam budidaya tanaman secara hidroponik. Kebutuhan nutrisi tanaman harus terpenuhi untuk mendapatkan pertumbuhan yang optimal (Indrawati et al, 2012). Selama ini sumber nutrisi yang digunakan untuk budidaya hidroponik adalah dengan pemberian pupuk anorganik berupa nutrisi $A$, nutrisi $B$ atau nutrisi $A B$ mix (Sutiyoso, 2006., Samanhudi dan Harjoko, 2010., Indrawati et al., 2012., Nugraha, 2014). Nutrisi diberikan ke tanaman dengan cara dilarutkan ke dalam air sehingga menjadi larutan nutrisi. Larutan nutrisi inilah yang dialirkan ke dalam media tanam (Hartus, 2007). Sayuran yang dibudidayakan akan menunjukkan respon pertumbuhan yang baik apabila nutrisi yang diberikan sesuai sehingga dapat diserap dengan baik oleh tanaman tersebut.

Petani memiliki kendala untuk memulai usaha hidroponik saat ini adalah nutrisi $A B$ Mix memiliki harga yang relatif mahal jika dibandingkan dengan pupuk majemuk dan pupuk organik cair. Dengan demikian, penelitian ini sangat penting dilakukan untuk meneliti nutrisi mana yang baik digunakan selain $A B$ Mix sebagai pengganti nutrisi untuk tanaman, sehingga para petani hidroponik terbantu dalam hal ekonomi. Menurut Kusumawardhani dan Widodo (2003), larutan nutrisi untuk budidaya hidroponik dapat diramu sendiri atau diganti dengan pupuk majemuk NPK, pupuk majemuk lengkap atau pupuk organik cair dengan catatan mengandung nutrisi yang cukup dan sesuai dengan kebutuhan tanaman.

Pupuk majemuk umumnya
mengandung unsur hara lebih dari satu macam, contohnya pupuk NPK. Menurut Juanita dan Lasut (2012), pupuk NPK biasanya dibuat dalam bentuk butiran yang seragam dan mudah untuk ditaburkan, bertekstur agak keras dengan permukaan licin sehingga dapat mengurangi sifat menarik air (higroskopis) dari udara lembab. Pupuk NPK adalah salah satu pupuk yang sering digunakan petani dengan kandungan dasar nitrogen $(N)$, fosfor $(P)$ dan kalium $(\mathrm{K})$ yang termasuk jenis pupuk majemuk yang dapat membantu pertumbuhan pertumbuhan tanaman yaitu pertumbuhan vegetatif dan generatif. Pupuk majemuk lengkap adalah pupuk yang mengandung unsur hara lebih banyak, misalnya unsur hara $\mathrm{N}, \mathrm{P}, \mathrm{K}, \mathrm{Mg}$, $\mathrm{Mn}, \mathrm{Bo}, \mathrm{Cu}, \mathrm{Co}$ dan $\mathrm{Zn}$ serta vitamin-vitamin untuk pertumbuhan tanaman. Menurut Halisah (2013), pemupukan menggunakan pupuk majemuk ini baiknya dilakukan melalui daun karena unsur hara lebih mudah diserap oleh daun dan dimanfaatkan dengan cepat oleh tanaman sehingga memacu pertumbuhan dan meningkatkan efisiensi metabolisme pada daun.

Salah satu pupuk yang dapat digunakan untuk menunjang pertumbuhan tanaman adalah pupuk organik cair (POC) yang merupakan larutan hasil dari pembusukan bahan-bahan organik yang berasal dari sisa tanaman, kotoran hewan dan manusia yang kandungan haranya lebih dari satu unsur. Pupuk organik cair mengandung banyak unsur hara makro, mikro, hormon dan asam amino yang dibutuhkan oleh tanaman (Darwin et al., 2017).

Berdasarkan uraian diatas, penulis tertarik untuk melakukan penelitian mengenai pengaruh perbedaan media tanam dan jenis nutrisi terhadap pertumbuhan tanaman pare (Momordica charantia L.).

\section{B. Tujuan Penelitian}

Penelitian ini bertujuan untuk mengetahui pengaruh jenis media tanam dan jenis nutrisi yang berbeda terhadap 
pertumbuhan dan produksi tanaman pare (Momordica charantia L.).

\section{METODOLOGI PENELITIAN}

\section{A. Tempat dan Waktu}

Penelitian ini telah dilaksanakan di Laboratorium Fakultas Pertanian Universitas Tamansiswa Palembang pada bulan April sampai Agustus 2019.

\section{B. Alat dan Bahan}

Alat yang digunakan pada penelitian ini adalah gunting, ember (ukuran 4 Liter), net pot plastik, gelas ukur $1000 \mathrm{ml}$, pH meter (PH-009A), TDS (TDS-3 merek HM Digital), kertas label, timbangan analitik (Kenmaster), cutter, tray, plastik dan steoroform, alat ukur panjang (Roll meter/Caliper).

Bahan yang digunakan adalah benih pare (Momordica charantia L.), arang sekam, cocopeat, air, rockwool, kain planel, nutrisi ABMix premium, pupuk NPK (Mutiara Biru), pupuk organik cair (S.Floran), pupuk majemuk lengkap (Growmore), ajiran.

\section{Metode Penelitian}

Penelitian ini menggunakan adalah Rancangan Acak Lengkap (RAL) faktorial dan menggunakan 2 faktor. Faktor pertama adalah jenis media tanam $(\mathrm{M})$ yang terdiri dari:

$$
\begin{array}{ll}
M_{1} & =\text { Rockwool } \\
M_{2} & =\text { Arang sekam } \\
M_{3} & =\text { Cocopeat }
\end{array}
$$

Sedangkan faktor kedua adalah jenis nutrisi larutan hidroponik $(\mathrm{K})$ yang terdiri dari :

$$
\begin{array}{ll}
\mathrm{K}_{1} & =\text { larutan AB Mix premium } \\
\mathrm{K}_{2} & =\text { pupuk NPK } \\
\mathrm{K}_{3} & =\text { pupuk organik cair } \\
\mathrm{K}_{4} & \text { = pupuk majemuk lengkap }
\end{array}
$$

Setiap perlakuan di ulang sebanyak 3 kali sehingga terdapat 36 unit tanaman.

\section{Prosedur Kerja}

Adapun prosedur kerja yang dilakukan pada penelitian ini adalah sebagai berikut:

\section{Penyiapan Media Tanam}

Sebelum melakukan penanaman terlebih dahulu mempersiapkan media tanam. Media serbuk kelapa (cocopeat) dibuat dengan cara dirontokkan dari sabut kelapa yang sebelumnya telah direndam selama 3 jam. Media arang sekam dibuat terlebih dahulu dengan menyiapkan sekam dalam kondisi kering, kemudian sekam dipanaskan hingga berwarna hitam kemudian segera disisihkan dan disiram dengan air untuk menghentikan pembakaran agar tidak menjadi abu arang sekam lalu dikeringkan. Setelah itu arang sekam ditimbang dan dimasukkan dalam wadah. Media tanam rockwool bisa didapatkan di toko pertanian.

\section{Penyemaian Benih}

Media semai yang berupa campuran arang sekam dan cocopeat disiapkan dengan mencampur keduanya dengan perbandingan 1:1. Benih yang akan disemai terlebih dahulu direndam, kemudian benih yang mengapung dibuang. Benih yang tenggelam diambil sebagai benih yang akan disemai. Benih kemudian disebar diatas media semai dan ditutup media semai lagi hingga tertutup. Selanjutnya media semai dibasahi dengan air. Setelah berumur 7 hari setelah semai (hss), diberikan larutan standar hidroponik (AB-Mix) dengan konsentrasi 200 ppm. Bibit semai dipindah tanam setelah umur 14 hari, selanjutnya konsentrasi dinaikkan menjadi $400 \mathrm{ppm}$.

\section{Pindah Tanam}

Kegiatan pindah tanam pada hidroponik sistem Wick dilakukan dengan cara mencabut bibit pare yang sudah berumur 14 hari, selanjutnya bibit dipindah kedalam gelas bekas 
air mineral yang sudah diberi media tanam sesuai perlakuan kemudian diletakkan dalam rangkaian hidroponik sistem Wick. Gelas mineral dipasang kain planel dan di buat lubang pada bagian bawah dan samping untuk memudahkan nutrisi masuk ke dalam media tanam.

\section{Pemeliharaan}

a. Nutrisi $A B$ Mix diberikan dengan cara melarutkan nutrisi yang akan dicobakan kedalam air hingga konsentrasi larutan menjadi 400 ppm. Pengukuran nilai ppm menggunakan alat TDS meter. Kemudian setiap minggu konsentrasi larutan naik 200 ppm hingga panen.

b. Pupuk NPK (mutiara biru)) dilarutkan dalam $1 / 2$ liter air dengan 3 gram pupuk NPK

c. Pupuk majemuk lengkap (Growmore) dilarutkan dalam $1 / 2$ liter air dengan 3 gram Growmore.

d. Pupuk organik cair (S.Floran) yang akan dicobakan kedalam air hingga konsentrasi larutan menjadi $400 \mathrm{ppm}$.

e. Pengendalian hama dan penyakit dilakukan secara manual dengan cara mengambil hama yang menyerang tanaman pare. Apabila tanaman terserang penyakit, sebaiknya segera dibuang untuk mencegah terjadinya penularan ke tanaman lain.

\section{Panen}

Panen dilakukan pada umur tanaman 4050 hari dengan cara memetik buah satu persatu.

\section{E. Peubah Yang Diamati}

Adapun pengamatan yang akan dilakukan yaitu :

\section{Panjang tanaman $(\mathrm{cm})$}

Pengukuran panjang tanaman dilakukan dengan menggunakan tali sebagai alat bantu dan diukur menggunakan roll meter/Caliper. Pengukuran dilakukan pada saat tanaman siap panen. Panjang tanaman diukur dari pangkal batang (permukaan media) hingga bagian titik tumbuh tanaman.

2. Jumlah daun (helai)

Jumlah daun dihitung dengan cara menghitung daun yang sudah membuka sempurna.

3. Umur berbunga (hari)

Umur berbunga dihitung pada saatbunga pertama mekar dari setiap tanaman contoh 75 $\%$ dari tanaman. Umur berbunga dihitung berdasarkan jumlah hari dari awal penanaman hingga berbunga untuk pertama kali.

4. Umur Panen (hari)

Pemanenan buah pare pertama dilakukan pada saat umur tanaman 40-50 hari setelah tanam. Selanjutnya dapat dilakukan panen setiap 2-4 hari sekali.

5. Jumlah Buah (buah)

Buah dihitung per tanaman saat tanaman sudah siap panen.

6. Bobot Buah pertanaman (gram)

Pengamatan dilakukan dengan cara menimbang berat semua buah yang sudah memenuhi kriteria panen yang dihasilkan tanaman.

\section{HASIL DAN PEMBAHASAN}

\section{A. Hasil}

Hasil analisis keragaman menunjukkan bahwa perlakuan pemberian

jenis media tanam dan jenis nutrisi larutan terhadap panjang tanaman, jumlah daun, umur berbunga, umur panen, jumlah buah, berpengaruh tidak nyata terhadap bobot buah dan pada perlakuan pemberian nutrisi berbeda sangat nyata terhadap peubah yang diamati. Sedangkan interaksi perlakukan dengan jenis 
media tanam dan jenis nutrisi larutan peubah yang diamati selama penelitian (Tabel menunjukkan pengaruh tidak nyata terhadap 2).

Tabel 2. Hasil analisis keragaman pengaruh perlakuan jenis media tanam dan larutan nutrisi terhadap peubah yang diamati

\section{F hitung}

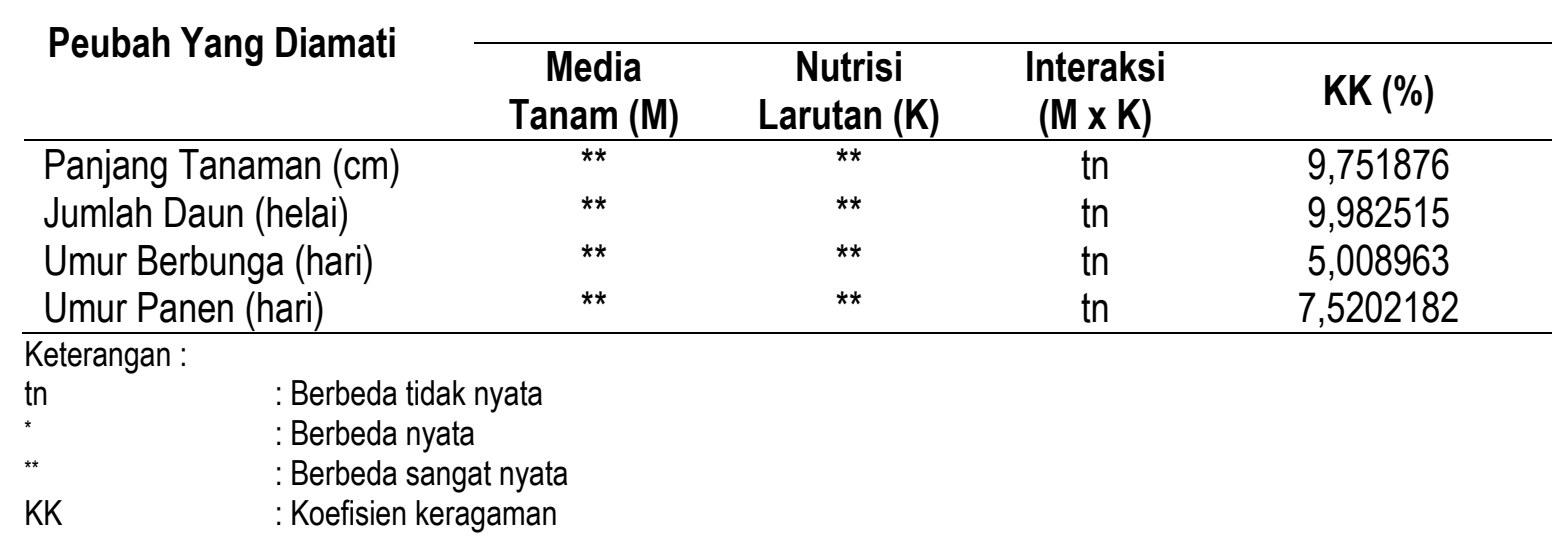

\section{B. Pembahasan}

\section{Panjang Tanaman $(\mathrm{cm})$}

Panjang tanaman pare (Momordica charantia L.) diukur dari pangkal batang (permukaan media) akar sampai bagian titik tumbuh tanaman, diukur setelah akhir penelitian.

Hasil akhir keseluruhan pengukuran panjang tanaman pare (Momordica charantia L.) dapat dilihat pada gambar 1. Panjang tanaman yang paling tinggi adalah perlakuan $\mathrm{M}_{3} \mathrm{~K}_{1}$ (media cocopeat dan nutrisi $A B$ Mix) dengan rata-rata $501,333 \mathrm{~cm}$ dan yang terendah adalah perlakuan $\mathrm{M}_{2} \mathrm{~K}_{4}$ (media arang sekam dan nutrisi pupuk majemuk lengkap) dan $\mathrm{M}_{3} \mathrm{~K}_{4}$ (media cocopeat dan nutrisi pupuk majemuk lengkap) dengan rata-rata $130,333 \mathrm{~cm}$. Media tanam dengan menggunakan sabut kelapa atau cocopeat memiliki daya simpan air yang tinggi, karena sabut kelapa sebagai media tanam memiliki karakteristik yang sanggup mengikat dan menyimpan air dengan kuat, sesuai untuk daerah panas, dan mengandung unsur-unsur hara esensial, semacam kalsium (Ca), magnesium $(\mathrm{Mg})$, kalium $(\mathrm{K})$, natrium $(\mathrm{N})$, dan fosfor (P) (Embarsari et al., 2015).

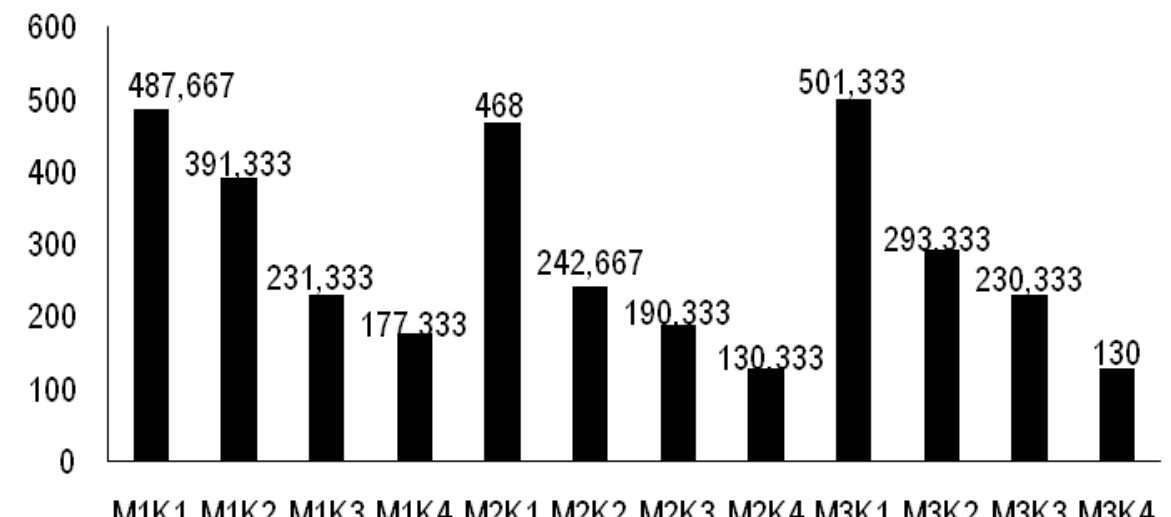

Gambar 1. Rata-rata panjang tanaman pare (Momordica charantia L.) (cm). 
Media cocopeat pada dasarnya memiliki kemampuan mengikat dan menyimpan air yang sangat kuat yang memiliki kapasitas menahan air cukup tinggi, memiliki pori mikro yang mampu menghambat gerakan air lebih besar sehingga menyebabkan ketersediaan air lebih tinggi (Embarsari et al., 2015). Pertumbuhan vegetatif tanaman ditunjukkan dengan pertambahan panjang, unsur hara yang berperan adalah nitrogen yang berfungsi untuk memacu pertumbuhan pada fase vegetatif terutama pada daun dan batang (Perwtasari, 2015). Sifat cocopeat yang senang menampung air dalam pori-pori menguntungkan karena akan menyimpan nutrisi lebih banyak yang dibutuhkan oleh tanaman terutama pada pertambahan tinggi tanaman. Perlakuan dengan menggunakan pupuk $A B$ mix memberikan hasil produksi dan kualitas tanaman lebih tinggi. Menurut Manullang et al. (2019), perlakuan dengan menggunakan pupuk $A B$ mix memiliki pertumbuhan vegetatif dan hasil panen terbaik pada tanaman. Kandungan pupuk $A B$ mix diduga memiliki komposisi seimbang yang dibutuhkan oleh tanaman. Komposisi hara seimbang yang dimaksud adalah kandungan unsur hara makro dan mikro yang dibutuhkan tanaman telah terkandung di dalam larutan hara $A B$ mix dan nutrisi yang diperoleh tanaman dari larutan hara $A B$ mix telah memenuhi kebutuhan tanaman.

Perlakuan $\mathrm{M}_{3} \mathrm{~K}_{1}$ (media cocopeat dan nutrisi $A B$ Mix) dan $\mathrm{M}_{2} \mathrm{~K}_{4}$ (media Arang Sekam dan pupuk majemuk lengkap) merupakan perlakuan terendah dalam pengamatan. Media tanam arang sekam memiliki karakteristik tidak mudah menggumpal, mempunyai porositas yang baik serta memiliki bobot yang ringan. Media tanam dalam hal ini merupakan salah satu faktor penting yang harus diperhatikan dalam melakukan budidaya tanaman, karena media tanam mempengaruhi pertumbuhan tanaman untuk memberikan hasil yang optimal, sebab media tanam yang baik untuk pertumbuhan dan perkembangan tanaman harus mempunyai sifat fisik yang baik antara lain gembur, serta mempunyai kemampuan untuk menahan air dan memiliki aerasi yang baik (Setyawan et al., 2018). Kekurangan unsur hara nitrogen menyebabkan tanaman tumbuh kerdil dan pertumbuhannya tersendat, serta daun berwarna hijau muda dan akhirnya kuning (Purwanti dan Susila, 2009). Perlakuan dengan pupuk majemuk lengkap hasilnya sangat rendah dari perlakuan yang lain karena disebabkan oleh kandungan hara yang terkandung di dalam pupuk tersebut belum mencukupi kebutuhan hara tanaman (Ohorella, 2012).

Nitrogen (N) adalah komponen utama dari berbagai substansi penting di dalam tanaman. Sekitar $\quad 40-50 \%$ kandungan protoplasma yang merupakan substansi hidup dari sel tumbuhan terdiri dari senyawa nitrogen. Nitrogen sangat dibutuhkan pada tahap pertumbuhan vegetatif, seperti pembentukan tunas, perkembangan batang dan daun (Handayani, 2017) dan kandungan $\mathrm{N}$ dalam pupuk yang digunakan tidak mencukupi kebutuhan tanaman.

Sumber larutan hara $A B$ mix yang digunakan pada sistem wick memberikan hasil yang terbaik dari pada menggunakan NPK menggunakan larutan nutrisi yang lain (Nugraha, 2014). Hal ini diperkuat oleh Hidayati (2009) bahwa ketersediaan unsur hara makro dan mikro yang cukup dan sesuai menyebabkan pertumbuhan tanaman akan terpacu secara optimal sehingga diperoleh hasil berupa panjang tanaman pare dengan kombinasi perlakuan nutrisi $A B$ mix dengan media cocopeat.

Pada penelitian dilapangan terbukti bahwa tanaman pare yang terpanjang adalah perlakuan $\mathrm{M}_{3} \mathrm{~K}_{1}$ (media cocopeat dan nutrisi $\mathrm{AB}$ Mix) dimana pertumbuhan panjang tanamannya lebih cepat dibandingkan dengan perlakuan yang lain. Hal ini diduga karena kombinasi 
media cocopeat dan nutrisi AB Mix mempunyai kemampuan yang tinggi dalam menyerap dan menyimpan larutan hara sehingga hara tersebut dapat dengan mudah tersedia bagi tanaman pada saat diperlukan.

Tabel 3. Uji BNJ pengaruh jenis media tanam terhadap panjang tanaman pare (Momordica charantia L.).

\begin{tabular}{lcc}
\hline \multicolumn{1}{c}{ Jenis Media Tanam $(M)$} & Rerata Panjang Tanaman & BNJ 5\%= 57,57 \\
\hline Rockwool $\left(M_{1}\right)$ & 321,92 & $\mathrm{a}$ \\
Arang Sekam $\left(\mathrm{M}_{2}\right)$ & 288,75 & $\mathrm{ab}$ \\
Cocopeat $\left(\mathrm{M}_{3}\right)$ & 257,82 & $\mathrm{~b}$ \\
\hline
\end{tabular}

Keterangan : Angka-angka yang diikuti oleh huruf yang sama pada kolom yang sama menunjukkan perbedaan yang tidak nyata pada taraf uji $5 \%$

Hasil uji lanjut pengaruh faktor jenis media tanam terhadap panjang tanaman menunjukkan bahwa $M_{1}$ (rockwool) berbeda tidak nyata dengan $\mathrm{M}_{3}$ (cocopeat) tetapi berbeda nyata dengan jenis media tanam $\mathrm{M}_{2}$ (Arang Sekam). Jenis media tanam yang memberikan hasil paling baik pada penelitian adalah jenis media tanam rockwool dengan rata-rata panjang tanaman 321,92 cm. Warman et al. (2016), media tanam rockwool mempunyai substrat partikel yang halus, lembut dan tidak mudah memadat apabila disiram air dalam jumlah yang banyak karena mempunyai drainase yang baik sehingga akar lebih bebas menyerap air ke dalam tanaman.

Nugraha (2018), menambahkan bahwa rockwool merupakan bahan non-organik yang terbuat dari campuran batuan basalt dan pasir yang berbentuk serat. Rockwool sebagai media tanam memiliki kelebihan, yakni bersih dan terlihat rapi, memiliki daya serap air yang tinggi sehingga penggunaan air lebih efisien, tidak mengandung bakteri yang berbahaya bagi tanaman, penggunaan pupuk/nutrisi lebih sedikit, sebagai isolator termal dan bising, serta kadar airnya dapat terkontrol dengan mudah.

Media tanam rockwool menunjukkan hasil rata-rata panjang tanaman yang terendah yaitu sebesar $257,82 \mathrm{~cm}$. Media cocopeat dapat menyimpan air dengan baik, tetapi banyak mengandung tanin. Zat tanin diketahui sebagai zat yang menghambat pertumbuhan tanaman (Nugraha, 2014).

Pertumbuhan vegetatif setiap tanaman sangat dipengaruhi oleh komponen hara diberikan. Presentase $\mathrm{N}$ yang berbeda pada fase vegetatif tanaman menyebabkan tanaman tersebut mengalami perbedaan dalam proses pertumbuhannya.

Tabel 4. Uji BNJ terhadap pengaruh jenis larutan nutrisi terhadap panjang tanaman pare (Momordica charantia L.).

\begin{tabular}{lcc}
\hline \multicolumn{1}{c}{ Jenis Larutan Nutrisi $(\mathrm{K})$} & Rerata Panjang Tanaman & BNJ 5\%= \\
\hline AB Mix $\left(\mathrm{K}_{1}\right)$ & 485,667 & $\mathrm{a}$ \\
Pupuk NPK $\left(\mathrm{K}_{2}\right)$ & 309,111 & $\mathrm{~b}$ \\
Pupuk Organik Cair $\left(\mathrm{K}_{3}\right)$ & 217,333 & $\mathrm{C}$ \\
Pupuk Majemuk Lengkap $\left(\mathrm{K}_{4}\right)$ & 145,889 & $\mathrm{~d}$ \\
\hline \multicolumn{2}{l}{ Keterangan : Angka-angka yang diikuti oleh huruf yang sama pada kolom yang sama } & menunjukkan perbedaan yang \\
\multicolumn{2}{l}{ tidak nyata pada taraf uji 5\% } &
\end{tabular}


Hasil uji BNJ pengaruh jenis larutan nutrisi terhadap panjang tanaman menunjukkan bahwa jenis larutan nutrisi $A B$ Mix $\left(K_{1}\right)$ berbeda tidak nyata dengan jenis larutan nutrisi $\mathrm{K}_{2}$ (pupuk NPK) tetapi berbeda sangat nyata dengan jenis larutan nutrisi $\mathrm{K}_{3}$ (pupuk organik cair) dan $\mathrm{K}_{4}$ (pupuk majemuk lengkap) terhadap panjang tanaman pare. AB Mix $\left(\mathrm{K}_{1}\right)$ merupakan jenis larutan nutrisi yang baik terhadap panjang tanaman dengan rata-rata 485,667 cm.

Nutrisi pada teknik hidroponik diberikan dalam bentuk larutan yang siap digunakan oleh tanaman dan disirkulasi. Dengan demikian, nutrisi dapat dengan mudah digunakan kembali oleh tanaman sesuai dengan kebutuhannya. Warman et al. (2016) menyatakan bahwa larutan nutrisi pada hidroponik mengandung semua nutrisi essensial dalam bentuk ion, sehingga mudah diserap oleh akar tanaman. Bila kekurangan atau kelebihan, akan mengakibatkan pertumbuhan tanaman terganggu dan hasil produksi yang didapatkan kurang maksimal. Larutan nutrisi hidroponik mengandung semua nutrisi mikro dan makro dalam jumlah sesuai, pupuk hidroponik juga bersifat lebih stabil dan cepat larut dalam air karena berada dalam bentuk lebih murni (Safriani, 2018).

Penggunaan jenis larutan nutrisi yang lain pada saat penelitian seperti pupuk NPK, pupuk organic cair (POC), dan pupuk majemuk lengkap memberikan hasil yang kurang maksimal. Pupuk majemuk adalah pupuk yang mengandung lebih dari satu unsur, biasanya disebut pupuk campuran (Palin, 2008). Pupuk majemuk dapat mengandung dua atau lebih unsur makro atau campuran makro mikro. Pengelompokan biasanya dilakukan berdasarkan jumlah dan jenis hara dalam pupuk majemuk. Pupuk majemuk 2 unsur hara seperti NP, NK, NMg, NS, NCa, dan CaS. Sedangkan pupuk majemuk 3 unsur yaitu menggabungkan 3 unsur hara seperti NPK (Palin, 2008).

\section{Jumlah Daun (helai)}

Jumlah daun tanaman pare (Momordica charantia L.) dihitung dengan cara menghitung daun yang sudah membuka sempurna dan dihitung setelah akhir penelitian. Rata-rata jumlah daun pada tanaman pare (Momordica charantia L.) dapat dilihat pada Gambar 2.

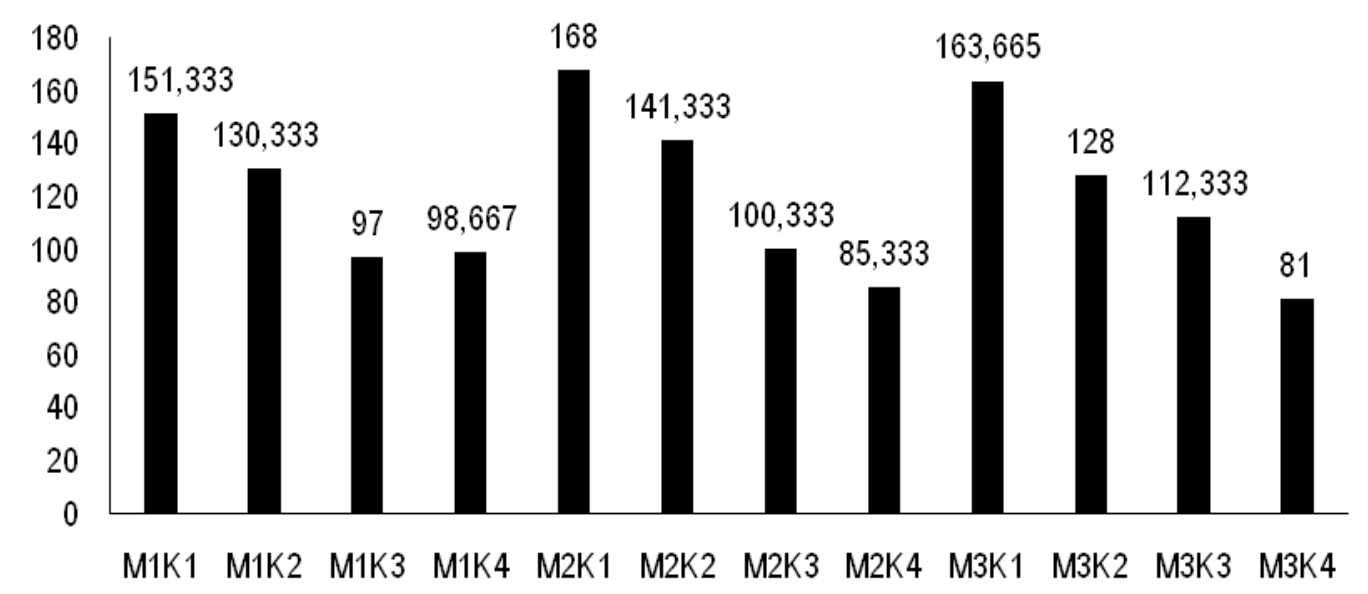

Gambar 2. Rata-rata jumlah daun tanaman pare (Momordica charantia L.) (helai) 
Pengamatan jumlah daun tanaman pare dapat dilihat pada gambar di atas, dimana jumlah daun tanaman yang paling banyak adalah perlakuan $\mathrm{M}_{2} \mathrm{~K}_{1}$ (media arang sekam dan nutrisi $A B$ Mix) dengan rata-rata 168 helai dan yang terendah adalah perlakuan $\mathrm{M}_{3} \mathrm{~K}_{4}$ (media cocopeat dan nutrisi pupuk majemuk lengkap) dengan rata-rata 81 helai.

Tanaman yang terpenuhi kebutuhan unsur haranya akan dapat merangsang pertumbuhan daun baru. Menurut Gustia (2013) bahwa tanaman yang cukup mendapat nitrogen akan tumbuh lebih hijau. Riyanti (2009) menambahkan, penambahan nitrogen pada tanaman dapat mendorong pertumbuhan organorgan yang berkaitan dengan fotosintesis seperti daun. Tanaman yang cukup mendapat suplai nitrogen akan membentuk daun yang memiliki helaian lebih luas dengan kandungan klorofil yang lebih tinggi, sehingga tanaman mampu menghasilkan karbohidrat/asimilat dalam jumlah yang tinggi untuk menopang pertumbuhan vegetatif. Hal ini sejalan dengan pendapat Warman et al. (2016) mengemukakan bahwa dengan meningkatnya jumlah daun tanaman maka akan secara otomatis meningkatkan berat segar tanaman. Daun pada tanaman sayuran merupakan organ yang banyak mengandung air, sehingga dengan jumlah daun yang semakin banyak maka kadar air tanaman akan tinggi dan menyebabkan berat tanaman semakin tinggi pula.

Arang sekam merupakan media tanam yang porous dan memiliki kandungan karbon (C) yang tinggi sehingga membuat media tanam ini menjadi gembur (Riyanti, 2009). Karakteristik lain arang sekam adalah sangat ringan, kasar sehingga sirkulasi udara tinggi karena banyak pori, kapasitas menahan air yang tinggi, warnanya yang hitam dapat mengabsorbsi sinar matahari secara efektif, pH tinggi $(8,5-9,0)$ serta dapat menghilangkan pangaruh penyakit khususnya bakteri dan gulma. Media arang sekam merupakan media tanam yang praktis digunakan karena tidak perlu disterilisasi, hal ini disebabkan mikroba patogen telah mati selama proses pembakaran. Selain itu, arang sekam juga memiliki kandungan karbon $(\mathrm{C})$ yang tinggi sehingga membuat media tanam ini menjadi gembur.

Larutan hidroponik yang ada pada media harus kaya akan nutrisi untuk pertumbuhan. Pada pertumbuhan vegetatif tanaman yang ditunjukkan dengan pertambahan panjang, unsur hara yang berperan adalah nitrogen $(\mathrm{N})$ yang berfungsi untuk memacu pertumbuhan pada fase vegetatif terutama daun dan batang (Hidayati, 2017).

Tabel 5. Uji BNJ pengaruh jenis media tanam terhadap jumlah daun tanaman pare (Momordica charantia L.).

\begin{tabular}{lcc}
\hline \multicolumn{1}{c}{ Jenis Media Tanam $(M)$} & Rerata Jumlah Daun & BNJ 5\% = 24,72 \\
\hline Rockwool $\left(M_{1}\right)$ & 123,75 & $a$ \\
Arang Sekam $\left(M_{2}\right)$ & 121,75 & $a$ \\
Cocopeat $\left(M_{3}\right)$ & 119,33 & a \\
\hline
\end{tabular}

Keterangan : Angka-angka yang diikuti oleh huruf yang sama pada kolom yang sama menunjukkan perbedaan yang tidak nyata pada taraf uji $5 \%$.

Tabel 5 menunjukkan bahwa Hasil uji lanjut pada pengaruh faktor jenis media tanam pada presentase jumlah daun menunjukkan media rockwool yang memiliki rata-rata tertinggi dari media yang lain mencapai 123,75 helai.
Media tanam rockwool merupakan media hidroponik yang paling baik karena memiliki porositas yang baik sehingga media dapat mengatur air dan udara yang diserap oleh tumbuhan (Miranda, 2017). 
Daun merupakan organ tanaman tempat mensintesis makanan untuk kebutuhan tanaman maupun sebagai cadangan makanan. Daun memiliki klorofil yang berperan dalam melakukan fotosintesis. Semakin banyak jumlah daun, maka tempat untuk melakukan proses fotosintesis lebih banyak sehingga fotosintat yang dihasilkan akan banyak juga, maka pengamatan daun sangat diperlukan selain sebagai indikator pertumbuhan juga sebagai data penunjang untuk menjelaskan proses pertumbuhan yang terjadi seperti pada pembentukan biomassa tanaman. Bahzar dan Santosa (2018) mengemukakan bahwa media sangat erat kaitannya dengan akar sebab media merupakan tempat pertumbuhan akar, tempat pijakan bagi akar serta pendukung penyerapan hara sehingga dengan media yang berbeda jenis maupun sifatnya maka pengaruhnya terhadap pertumbuhan dan perkembangan akar juga berbeda.

Tabel 6. Uji BNJ pengaruh jenis larutan nutrisi terhadap jumlah daun tanaman pare (Momordica charantia L.).

\begin{tabular}{lcc}
\hline \multicolumn{1}{c}{ Jenis Larutan Nutrisi $(\mathrm{K})$} & Rerata Jumlah Daun & BNJ 5\%= 27,30 \\
\hline AB Mix $\left(\mathrm{K}_{1}\right)$ & 161,000 & $\mathrm{a}$ \\
Pupuk NPK $\left(\mathrm{K}_{2}\right)$ & 133,222 & $\mathrm{~b}$ \\
Pupuk Organik Cair $\left(\mathrm{K}_{3}\right)$ & 103,222 & $\mathrm{C}$ \\
Pupuk Majemuk Lengkap $\left(\mathrm{K}_{4}\right)$ & 88,333 & $\mathrm{C}$ \\
\hline \multicolumn{2}{c}{ Keterangan : Angka-angka yang diikuti oleh huruf yang sama pada kolom yang sama } \\
tidak nyata pada taraf uji $5 \%$
\end{tabular}

Hasil uji BNJ menunjukkan bahwa jenis larutan nutrisi $A B$ Mix $\left(K_{1}\right)$ berbeda tidak nyata dengan jenis larutan nutrisi $K_{2}$ (pupuk NPK) tetapi berbeda sangat nyata dengan jenis larutan nutrisi $\mathrm{K}_{3}$ (pupuk organik cair) dan $\mathrm{K}_{4}$ (pupuk majemuk lengkap). Jenis larutan nutrisi yang sangat berpengaruh yaitu $A B$ Mix dengan rata-rata 161,000 helai. Banyak sedikitnya jumlah daun antara lain dipengaruhi oleh unsur hara nitrogen yang terkandung di dalam larutan nutrisi. Nitrogen adalah komponen utama dari berbagai subtansi penting di dalam pembentukan daun tanaman. Nitrogen juga dibutuhkan untuk membentuk senyawa penting seperti klorofil, asam nukleat, dan enzim (Furoidah, 2018).

Semua hara yang terkandung pada nutrisi hidroponik adalah unsur esensial yang diperlukan tanaman dalam pertumbuhan dan perkembangannya. Apabila unsur hara makro dan mikro tidak lengkap ketersediaannya, dapat menghambat pertumbuhan dan perkembangan tanaman (Siregar, 2017). Pertumbuhan dan perkembangan tanaman erat hubungannya dengan kedua faktor tersebut, apabila salah satu atau semua faktor tidak mendukung maka pertumbuhan dan perkembangan tanaman tidak dapat berjalan dengan baik (Siregar, 2017).

\section{Umur Berbunga (hari)}

Umur berbunga tanaman pare (Momordica charantia L.) dilakukan saat bunga pertama mekar dari setiap tanaman dan umur berbunga dihitung berdasarkan jumlah hari dari awal penanaman hingga berbunga untuk pertama kalinya.

Hasil pengamatan umur berbunga pada tanaman pare (Momordica charantia L.) dapat dilihat pada Gambar 3. 


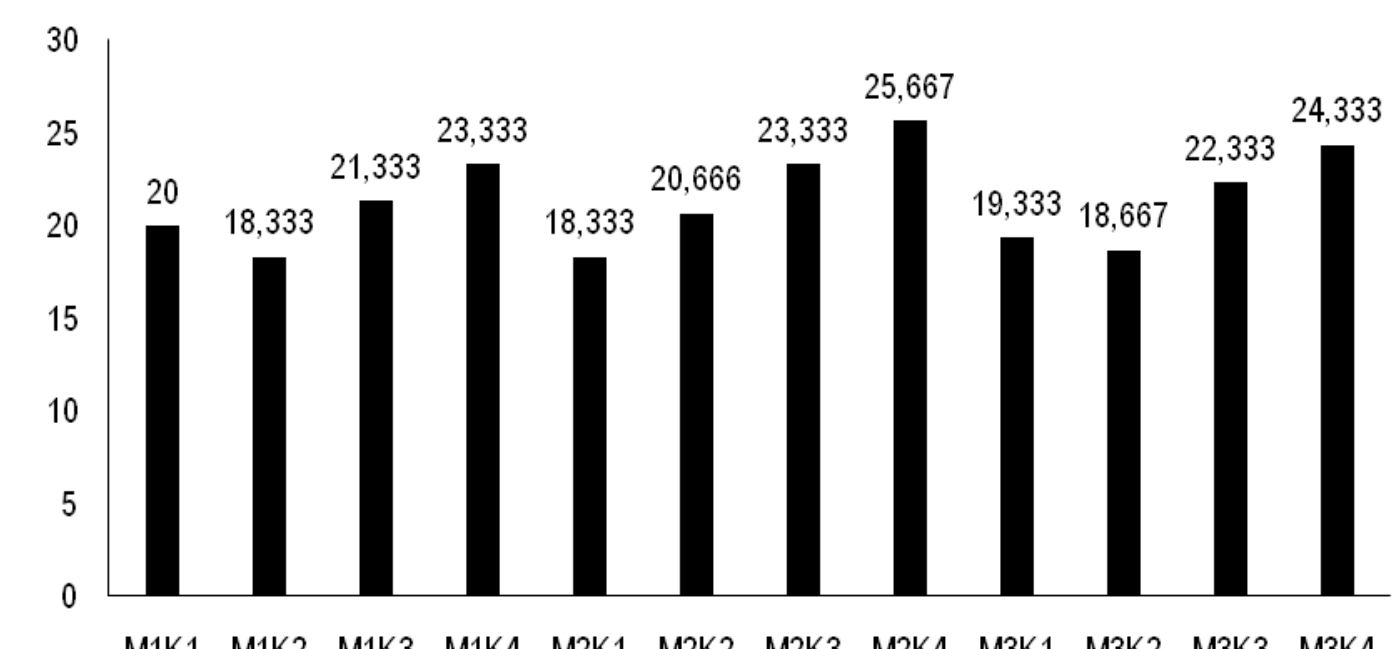

Gambar 3. Rata-rata umur berbunga tanaman pare (Momordica charantia L.) (hari)

Pengamatan umur berbunga tanaman pare dapat dilihat pada Gambar di atas, dimana umur berbunga tanaman yang paling cepat adalah perlakuan $\mathrm{M}_{1} \mathrm{~K}_{2}$ (media arang sekam dan pupuk NPK) dan $\mathrm{M}_{2} \mathrm{~K}_{1}$ (media arang sekam dan nutrisi $A B$ Mix) dengan rata-rata 18,333 hari dan yang terlambat adalah perlakuan $\mathrm{M}_{2} \mathrm{~K}_{4}$ (media arang sekam dan nutrisi pupuk majemuk lengkap) dengan rata-rata 25,667 hari.

Media tanam arang sekam mampu menyerap dan menyimpan air (Embarsi, 2015), selain itu juga arang sekam juga berperan penting dalam perbaikan struktur media tanam sehingga aerasi dan drainase di media tanam menjadi lebih baik dan media arang sekam juga memiliki kandungan karbon sehingga media tanam tersebut menjadi media yang ideal yang mampu menghantarkan nutrisi yang diberikan menjadi mudah diserap oleh tanaman.

Menurut Fransiska et al. (2016) pupuk majemuk khususnya NPK, memiliki kelebihan dibandingkan dengan pupuk tunggal, yaitu lebih mudah aplikasinya, lebih lengkap dan seimbang kandungan unsur haranya, lebih efisien dalam penggunaan tenaga kerja dan waktu, serta lebih mudah pengadaan dan penyimpanannya tetapi menegaskan bahwa jika kekurangan atau kelebihan salah satu unsur hara dapat mengurangi efisiensi unsur hara lainnya. Menurut Marsono (2003) bahwa unsur hara P berperan membantu asimilasi, respirasi sekaligus mempercepat pembungaan, pemasakan biji dan buah. Keadaan ini disebabkan dengan pemberian pupuk NPK Mutiara dapat meningkatkan ketersediaan dan serapan unsur hara $\mathrm{N}, \mathrm{P}$, dan $\mathrm{K}$ serta $\mathrm{Ca}$ dan $\mathrm{Mg}$ oleh tanaman pare. Dengan makin tersedianya unsur hara makro tersebut dapat memacu pertumbuhan dan perkembangan tanaman yang selanjutnya dapat memberikan hasil buah yang tinggi. Seperti dinyatakan oleh Neli (2017) bahwa tanaman akan tumbuh dengan subur apabila elemen (unsur hara) yang dibutuhkannya tersedia cukup dan unsur hara tersebut tersedia dalam bentuk yang dapat diserap oleh tanaman.

Nugraha (2018) menambahkan bahwa perlakuan dengan menggunakan pupuk $A B$ mix memiliki pertumbuhan vegetatif dan hasil panen terbaik pada tanaman, misalnya sawi, tomat, pakchoy dan selada. Kandungan pupuk $A B$ mix diduga memiliki komposisi seimbang yang dibutuhkan oleh tanaman. Komposisi hara seimbang yang dimaksud adalah kandungan 
unsur hara makro dan mikro yang dibutuhkan tanaman telah terkandung di dalam larutan hara $A B$ mix dan nutrisi yang diperoleh tanaman dari larutan hara $A B$ mix telah memenuhi kebutuhan tanaman. Pada pengamatan yang dilakukan, perlakukan yang agak lambat berbunga yaitu dengan nutrisi larutan pupuk majemuk lengkap. pengamatan yang dilakukan, penggunaan pupuk majemuk lengkap merupakan hasil yang terendah dikarenakan unsur fosfor $(P)$ yang terkandung dalam pupuk yang digunakan saat penelitian tidak mencukupi kebutuhan tanaman.
Dengan demikian, adanya kerjasama antara media tanam dan pemberian nutrisi, dalam memberikan unsur hara yang dibutuhkan tanaman. Salah satu fungsi perlakuan nutrisi yaitu dapat memenuhi kebutuhan unsur hara yang dibutuhkan tanaman sehingga dengan bantuan media tanam yang bersifat steril dan kaya unsur hara. Tanaman dapat menyerap hara selain dari larutan nutrisi juga dapat hara dari media tanaman terutama dari media tanam arang sekam dan rockwool (Trikoriantono, 2018).

Tabel 7. Uji BNJ pengaruh jenis larutan nutrisi terhadap umur berbunga tanaman pare (Momordica charantia L.).

\begin{tabular}{lcc}
\hline \multicolumn{1}{c}{ Jenis Larutan Nutrisi $(\mathrm{K})$} & $\begin{array}{c}\text { Rerata Umur } \\
\text { Berbunga }\end{array}$ & BNJ 5\% 47,58 \\
\hline AB Mix $\left(\mathrm{K}_{1}\right)$ & 19,222 & $\mathrm{a}$ \\
Pupuk NPK $\left(\mathrm{K}_{2}\right)$ & 19,222 & $\mathrm{a}$ \\
Pupuk Organik Cair $\left(\mathrm{K}_{3}\right)$ & 22,333 & $\mathrm{~b}$ \\
Pupuk Majemuk Lengkap $\left(\mathrm{K}_{4}\right)$ & 24,444 & $\mathrm{~b}$ \\
\hline Keterangan: & angka-angka yang diikuti oleh huruf yang sama pada kolom yang sama menunjukkan perbedaan yang \\
\multicolumn{2}{l}{ tidak nyata pada taraf uji 5\%. }
\end{tabular}

Hasil uji lanjut pada Tabel 8 menunjukkan bahwa jenis larutan nutrisi $A B$ Mix $\left(K_{1}\right)$ dan $K_{2}$ (pupuk NPK) tidak berbeda nyata dengan jenis larutan nutrisi $\mathrm{K}_{3}$ (pupuk organik cair) dan $\mathrm{K}_{4}$ (pupuk majemuk lengkap). Jenis larutan nutrisi yang sangat berpengaruh yaitu $A B$ Mix dan pupuk NPK dengan rata-rata 19,222 hari.

Menurut Furoidah (2018), salah satu fungsi phospor adalah membantu proses asimilasi dan respirasi. Kandungan nitrogen dan phospor dalam larutan nutrisi yang mencukupi untuk pertumbuhan dan perkembangan tanaman yaitu $8 \%$ dan $10 \%$. Dalam hal ini unsur hara makro yang terkandung dalam $A B$ Mix dapat memenuhi kebutuhan pertumbuhan tanaman pare. Ditambahkan oleh Sundari et al. (2016) pupuk/nutrisi hidroponik AB Mix adalah pupuk yang telah diformulasikan khusus dari garam-garam mineral yang larut dalam air, mengandung unsur-unsur hara penting yang diperlukan tanaman untuk tumbuh dan perkembangan tanaman. Hasil pengamatan memperlihatkan pemberian pupuk $A B$ Mix sebanyak 1000 ppm mampu memberikan hasil yang baik untuk pertumbuhan tanaman, jika dilihat dari rata-rata umur berbunga.

\section{Umur Panen (hari)}

Berdasarkan data hasil analisa keragaman dan penelitian dilapangan menunjukkan bahwa perlakuan dengan berbagai jenis media tanam dan jenis nutrisi tidak memberikan hasil yang maksimal sampai produksi, dimana perlakuan yang mencapai umur panen yaitu $M_{1} K_{1}$ (media rockwool dan nutrisi $A B-M i x), M_{2} K_{1}$ (media arang sekam dan AB-Mix) dan $\mathrm{M}_{3} \mathrm{~K}_{1}$ (cocopeat dan AB-Mix). Dengan demikian perlakuan yang lain tidak mencapai umur panen tetapi bakal buah telah muncul pada umur 30 hari dan kemudian menguning dan tidak bisa mencapai produksi. Nutrisi yang diberikan pada tanaman harus 
dalam komposisi yang tepat. Bila kekurangan atau kelebihan akan mengakibatkan pertumbuhan tanaman terganggu dan hasil produksi yang diperoleh pun kadang kurang maksimal (Bahzar, 2018).

Nutrisi $A B$ Mix memiliki unsur hara yang lengkap untuk menunjang pertumbuhan tanaman, Wijayanti (2012) menyatakan tanaman dengan hara $A B$ Mix menghasilkan tinggi, bobot, bobot buah layak konsumsi lebih tinggi dari hara dengan pupuk majemuk lainnya pada tanaman sayur sawi.

Menurut Tripama dan Rizal (2018) larutan hara makro dan mikro dalam $A B$ Mix terdiri dari $\mathrm{NH} 4 \mathrm{NO} 31.2 \mathrm{mmol} / \mathrm{l}, \mathrm{KNO} 39.5$ $\mathrm{mmol} / \mathrm{l}, \quad \mathrm{Ca}(\mathrm{NO} 3) 2 \quad 5.4 \mathrm{mmol} / \mathrm{l}, \mathrm{MgSO} 42.4$ $\mathrm{mmol} / \mathrm{l}, \mathrm{K} 2 \mathrm{SO} 44.4 \mathrm{mmol} / \mathrm{l}, \mathrm{KH} 2 \mathrm{PO} 41.5 \mathrm{mmol} / \mathrm{l}$. Larutan hara mikro terdiri dari Fe EDTA

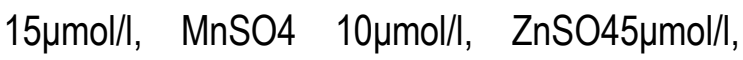
H3BO3 $30 \mu \mathrm{mol} / \mathrm{l}$, CuSO4 $0.75 \mu \mathrm{mol} / \mathrm{l}$, NH4$\mathrm{MoO} 40.5 \mu \mathrm{mol} / \mathrm{l}$. Pengamatan yang dilakukan, keberhasilan tanaman pare sampai dengan produksi yaitu penggunaan larutan $A B$ Mix dengan semua jenis media. Dengan demikian perlakuan antara media dan jenis larutan pada umur panen tidak nyata.

\section{Jumlah Buah (buah)}

Penelitian dilapangan menunjukkan bahwa perlakuan yang mencapai tahap berbuah yaitu perlakuan $M_{1} K_{1}, M_{2} K_{1}, M_{3} K_{1}$. Pelakuan yang lain tidak sampai pada tahap berbuah yang maksimal rata-rata hanya mencapai umur 30 hari setelah muncul bakal buah kemudian buah tersebut menguning, layu dan gagal produksi. Hasil dari penelitian ini dengan larutan nutrisi $A B$ Mix memberikan pengaruh terhadap jumlah kebutuhan unsur hara pada masingmasing tanaman pare. Pada dasarnya nutrisi larutan hidroponik yang diberikan mempunyai komposisi kandungan unsur hara makro dan mikro sesuai dengan standard yang direkomendasikan. Pada penelitian yang dilakukan perlakuan antara rockwool dan $A B$ Mix memiliki rata-rata jumlah buah 5 , perlakuan arang sekam dan $A B$ Mix memiliki rata-rata 6 dan perlakuan dengan cocopeat dan $A B$ Mix memiliki rata-rata buah 1 .

Tabel 8. Jumlah buah tanaman pare (Momordica charantia L.) yang mencapai produksi.

\begin{tabular}{llc}
\hline No & \multicolumn{1}{c}{ Perlakuan } & Jumlah Buah \\
\hline 1 & $M_{1} K_{1}$ (Media rockwool dan nutrisi AB-Mix premium & 7 \\
2 & $M_{2} K_{1}$ (Media arang sekam dan nutrisi AB Mix premium) & 9 \\
3 & $M_{3} K_{1}$ (Media cocopeat dan nutrisi AB-Mix premium) & 5 \\
\hline
\end{tabular}

Kebutuhan unsur hara pada tanaman selain berkaitan dengan jenis unsur hara, juga sangat berkaitan dengan jumlah unsur hara yang dibutuhkan. Jumlah unsur hara yang dibutuhkan oleh tanaman berbeda sesuai dengan jenis tanaman dan jenis unsur haranya. Pada jenis tanaman sayuran membutuhkan unsur hara yang berbeda dengan jenis tanaman palawija (Raihan, 2017).

Kandungan pupuk nutrisi anorganik komersial diduga memiliki komposisi seimbang yang dibutuhkan oleh tanaman. Komposisi hara seimbang yang dimaksud adalah kandungan unsur hara makro dan mikro yang dibutuhkan tanaman telah terkandung di dalam larutan hara nutrisi anorganik komersial dan nutrisi yang diperoleh tanaman dari larutan hara nutrisi anorganik komersial telah memenuhi kebutuhan tanaman (Raihan, 2017).

Pupuk A mengandung unsur kalsium yang dalam keadaan tidak boleh dicampur dengan sulfat dan fosfat yang terdapat dalam pupuk B. Hal ini perlu dihindarkan agar tidak terjadi proses pengendapan yang mengakibatkan unsur-unsur tersebut tidak terserap oleh tanaman. Apabila kation kalsium 
dalam pupuk $A$ bertemu dengan anion sulfat dalam pupuk $B$ akan terjadi endapan kalsium sulfat sehingga kalsium dan sulfat tidak dapat diserap oleh akar tanaman. Tanaman pun akan menunjukkan gejala defisiensi kalsium dan sulfur. Begitupula bila kation kalsium bertemu dengan anion fosfat akan terjadi endapan Ferry Fosfat sehingga unsur kalsium dan besi tidak dapat diserap oleh akar (Hayati, 2006).

Tanaman untuk dapat tumbuh dan berproduksi dengan baik membutuhkan unsur hara yang selalu tersedia selama siklus hidupnya mulai dari penanaman hingga panen. Ketersediaan hara dalam tanah dipengaruhi oleh banyak faktor. Faktor pemberian konsentrasi pupuk yang tepat akan mempengaruhi hasil suatu tanaman. Upayaupaya untuk menjaga ketersediaan hara dalam tanah selain pemberian konsentrasi pupuk, dapat juga melalui frekuensi pemberian pupuk, cara pemberian dan bentuk pupuk digunakan secara tepat (Sundari et al., 2016).
Pertumbuhan dan hasil tanaman yang optimum dapat dicapai dengan pemberian larutan hara sesuai dengan kebutuhan tanaman. Meskipun unsur hara tanaman sangat kompleks, tetapi demikian kebutuhan dasar terhadap hara dalam budidaya tanaman secara hidroponik telah diketahui Terdapat 14 unsur hara essensial untuk pertumbuhan tanaman (Ardani dan Akur, 2019).

\section{Bobot Buah (gram)}

Penelitian dilapangan menunjukkan bahwa sesuai dengan jumlah buah yang didapat maka bobot buah yang yang tertinggi adalah perlakukan media arang sekam dan nutrisis $A B$ Mix $\left(\mathrm{M}_{2} \mathrm{~K}_{1}\right)$ mencapai 885 gram kemudian perlakuan media rockwool dan nutrisi $A B$ Mix mencapai 750 gram dan perlakuan media cocopeat dan nutrisiAB Mix mencapai 384 gram.

Tabel 9. Bobot buah tanaman pare (Momordica charantia L.) yang mencapai produksi.

\begin{tabular}{llc}
\hline No & \multicolumn{1}{c}{ Perlakuan } & Rata-rata $(\mathbf{g})$ \\
\hline 1 & $\mathrm{M}_{1} \mathrm{~K}_{1}$ (Media rockwool dan nutrisi AB-Mix premium & 750 \\
2 & $\mathrm{M}_{2} \mathrm{~K}_{1}$ (Media arang sekam dan nutrisi AB Mix premium) & 885 \\
3 & $\mathrm{M}_{3} \mathrm{~K}_{1}$ (Media cocopeat dan nutrisi AB-Mix premium) & 384 \\
\hline
\end{tabular}

Larutan nutrisi merupakan kebutuhan yang sangat vital dalam budidaya secara hidroponik, karena tanaman yang dibudidayakan dengan sistem tersebut hanya mendapat asupan nutrisi dan larutan nutrisi yang disediakan Menurut Riana et al. (2015), formulasi larutan nutrisi berbeda-beda dan sangat bergantung dari beberapa variabel berikuti ini, spesies dan varietas tanaman, tahap penumbuhan tanaman, bagian tanaman yang ingin dipanen atau dikonsumsi, musim (panjang hari), dan cuaca (suhu, intensitas, cahaya, dan lama penyinaran).
Raihan (2017) mengemukakan bahwa Bahan baku yang digunakan untuk pembuatan lautan nutrisi untuk Budidaya hindroponik harus memilliki sifat larutan sempurna dan dapat larut didalam air. Terdapat 12 jenis bahan kimia yang mengandung unsur-unsur yang berguna bagi tanaman. Unsur-unsur tersebut dibagi kedalam dua kelompok unsur, yaitu unsur makro dan unsur mikro. Unsur makro terdiri atas Nitrogen $(N)$, Fosfor (P), Kalium (K), Sulfur (S), Kalsium $(\mathrm{Ca})$, dan Magnesium (Mg), sadangkan unsur hara mikro terdiri dari Boron (B), Tembaga $(\mathrm{Cu})$, Besi (Fe), Mangan (Mn), Seng (Zn) dan Molibdenum (Mo). 
Unsur hara yang utama dibutuhkan oleh tanaman sayuran adalah $\mathrm{N}, \mathrm{P}$, dan K. Nitrogen adalah unsur hara yang paling dinamis di alam. Unsur $\mathrm{N}$ mudah hilang dari tanah melalui volatilisasi atau perkolasi air tanah, mudah berubah bentuk, dan mudah pula diserap tanaman. Tanaman menyerap unsur $\mathrm{N}$ dalam bentuk ammonium (NH4+) dan nitrat (NO3). Keberadaan $\mathrm{NH} 4+$ sangat dinamis mudah berbentuk menjadi NO3- akibat proses nitrifikasi (Warman et al., 2016). Fosfor adalah unsur hara yang tidak mudah bergerak (immobile) dalam tanah. Unsur hara $\mathrm{P}$ di tanah tersedia dalam jumlah cukup bagi tanaman, namun kekurangan unsur hara $\mathrm{P}$ menyebabkan pertumbuhan tanaman mcnjadi terhambat akibat terganggunya perkembangan sel dan akar pada tanaman, metabolisme karbohidrat, dan transfer energy (Liferdi, 2010)

Menurut Dimas et al. (2018), kalium sebagai unsur hara esensial penting seperti $\mathrm{N}$. Meski hanya sebagian kecil $\mathrm{K}$ tersedia yang dapat dimanfaatkan oleh tanaman, hara $\mathrm{K}$ mudah bergerak dan terikat oleh permukaan koloid tanah. Kekurangan $\mathrm{K}$ mempengaruhi sistem perakaran, tunas, pembentukan pati, dan translokasi gula.

Tanaman dapat menyerap unsur hara melalui akar dan daun. Unsur $\mathrm{C}$ dan $\mathrm{O}$ diambil tanaman dari udara dalam bentuk $\mathrm{CO} 2$ melalui stomata daun dalam proses fotosintesis. Unsur $\mathrm{H}$ diambil tanaman dari air tanah $(\mathrm{H} 2 \mathrm{O})$ melalui akar tanaman. Air juga diserap tanaman melalui daun tapi dalam jumlah yang sedikit. Unsurunsur yang lain diserap oleh akar tanaman dari dalam tanah seperti unsur hara makro juga unsur hara mikro (Raihan, 2017).

\section{KESIMPULAN DAN SARAN}

\section{A. Kesimpulan}

1. Kombinasi perlakuan jenis media tanam dan jenis nutrisi yang menunjukkan hasil terbaik sampai produksi adalah $\mathrm{M}_{2} \mathrm{~K}_{1}$ (arang sekam dan nutrisi AB Mix) karna arang sekam memiliki kandungan karbon yang tinggi sehingga selalu gembur dan memiliki karakteristik yang ringan, kasar dan sirkulasi udara tinggi karena banyak pori, kapasitas menahan air yang baik serta warnanya yang hitam dapat mengabsorbsi sinar matahari sedangkan nutrisi $A B$ Mix memiliki komposisi hara seimbang yaitu kandungan makro dan mikro yang dibutuhkan tanaman.

2. Kombinasi perlakuan jenis media tanam dan jenis nutrisi terendah sampai produksi adalah $\mathrm{M}_{3} \mathrm{~K}_{4}$ (media cocopeat dan nutrisi pupuk majemuk lengkap) karena media cocopeat mengandung senyawa tanin (suatu senyawa metabolit sekunder dari beberapa tanaman) yang mengikat dan mengendapkan protein, mengandung unsur klor yang cukup tinggi dan serta berdaya serap air tinggi yang sering menyebabkan akar menjadi busuk, sedangkan pupuk majemuk lengkap memiliki kandungan hara yang belum mencukupi kebutuhan tanaman.

\section{B. Saran}

Untuk menghasilkan pertumbuhan dan produksi tanaman pare (Momordica charantia L.) disarankan menggunakan nutrisi dengan unsur hara makro dan mikro yang cukup bagi tanaman sehingga memberikan hasil yang terbaik.

\section{DAFTAR PUSTAKA}

Ardani., Akur, P. 2019. Pengaruh Pupuk Organik Cair Nasa dan Pupuk NPK Mutiara terhadap Pertumbuhan dan Hasil Tanaman Tomat (Lycopersicum esculentum Mill) Varietas Servo $F_{1}$. Jurnal agrifor. Vol xviii(1).

Arif, M.A. 2010. Pengaruh Pupuk Organik Biogreen terhadap Produksi Tanaman 
Pare (Momordica Charantia L.). Jurnal Biologi Tropis Volume 16 (2): 1-9.

Bastari, I.L., Sipayung, R.., Ginting, J. 2017. Respon Pertumbuhan dan Produksi Paria Terhadap Beberapa Komposisi Media Tanam dan Pemberian Pupuk Organik Cair. Jurnal Agroteknologi FP USU, Vol 5(4) : 740-748.

Bahzar, S. 2018. Pengaruh Nutrisi yang diberikan Terhadap Pertumbuhan Tanaman Pakcoy yang ditanam secara Hidroponik. Jurnal Sainsmatika. Vol 14(1):28-44.

Bahzar, H., Santosa, M. 2018. Pengaruh Nutrisi dan media Tanaman Terhadap Pertumbuhan dan Hasil Tanaman Pakcoy (Brassica rapa L. var. chinensis) dengan Sistem Hidroponik Sumbu. Jurnal Produksi Tanaman. Vol 6(7):12731281

Darwin, H.P., Yohanes, C., Lucky., Hairani, F. 2017. Aplikasi Pupuk Organik Cair dan Pupuk Anorganik terhadap Pertumbuhan, Produksi dan Kualitas Pasca Panen Jagung Manis (Zea mays Var. Saccharata Sturt.). jurnal Hortikultura Indonesia 8(1):59-67.

Dimas, S., Medha, B., Ninuk, H. 2018. Pengaruh Media Tanam pada Sistem Vertikultur terhadap Pertumbuhan dan Hasil Tanaman Bayam Merah (Amaranthus tricolor L.). jurnal Produksi Tanaman. Vol 6(2):210-216.

Embarsari, R., Ahmad, I., Budi, F. 2015. Pertumbuhan dan Hasil Selendri pada Sistem Hidroponik Sumbu dengan Jenis Media Tanam Berbeda. Jurnal Agro. Vol 2(2).

Fransiska, P., Edison, A., Melkizedek, N., Marwoto. 2016. Pengaruh Waktu Aplikasi Pupuk NPK Phonska terhadap Pertumbuhan dan Hasil Kedelai. Prossiding Seminar Hasil Pnelitian. Jakarta
Furoidah, N. 2018. Peranan Keankaragaman Hayati untuk Mendukung Indonesia sebagai Lumbung Pangan Dunia. Seminar Nasional. Vol 16(2).

Gustia, P. 2013. Aplikasi Pupuk Organik cair dan Pupuk Anorganik terhadap Pertumbuhan, Produksi dan Kualitas Pasca panen Jagung Manis. Jurnal Horti. Vol 14 (1):38-44.

Halisah. 2013. Pengaruh Konsentrasi Pupuk Growmore dan Interval Waktu terhadap Pertumbuhan dan Produksi Tanaman Kedelai (Glycine max L. Mcrrill). [Skripsi]. Universitas Teuku Umar Meulaboh: Aceh Barat.

Hartus,T. 2007. Berkebun Hidroponik Secara Murah. Penebar Swadaya. Jakarta. 96 $\mathrm{h} / \mathrm{m}$.

Hernawati. 2011. Potensi Buah Pare (Momordica Charantia L.) sebagai Herbal Antifertilitas. Jurnal Biologi, Vol 1(2).

Handayani, N. P. 2017. Kandungan Nitrogen dan kalium pada Pupuk Organik Cair Kombinasi Kulit Pisang dan Lamtoro dengan Variasi Penambahan Jerami Padi. [Skripsi]. Universitas Muhammadiyah. Surakarta.

Hayati, M. 2006. Penggunaan Sekam padi Sebagai Media Alternatif dan Pengujian Efektifitas Penggunaan Pupuk dan terhadap Hasil Tanaman Tomat secara Hidroponik. Jurnal Floratek. Vol 2:63-68

Hidayati, N. 2009. Reaksi Nutrisi AB Mix dengan Berbagai Media Tanam. Jurnal Horti. Vol. 5(1).

Hidayati, N. 2017. Kajian Penggunaan Nutrisi Anorganik terhadap Pertumbuhan Kangkun. Jurnal Agro. Vol 4(2):75-81

Indrawati, R., Didik, I., Sri, N. 2012. Pengaruh Komposisi Media Tanam dan Kadar Nutrisi Hidroponik Terhadap pertumbuhan dan Hasil Tomat (Lycopersicum esculentum). [Skripsi]. Universitas Gadjah Mada: Yogyakarta. 
Juanita, D., Lasut. 2012. Pengaruh Pemberian Pupuk NPK terhadap Pertumbuhan Bibit Gyrinops Versteegii. Jurnal IImu Kehutanan, Vol 2(1).

Kusumawardhani, A dan Widodo, WD. 2003. Pemanfaatan Pupuk Majemuk sebagai sumber hara tomat secara hidroponik. Buletin Agron (31)(1):15-20.

Miranda, S. 2017. Efektivitas Cocopeat dan Arang Sekam dan Mensubstitusi Media Tanam Rockwool pada Tanaman Mint (Mentha arvensis L.) secara Hidroponik dengan Sistem Sumbu. [Skripsi]. Universitas Jambi. Jambi.

Marsono, N. 2003. Pengaruh Pemberian Pupuk Organik terhadap beberapa Media tumbuh Pertumbuhan dan Produksi Tanaman pakcoy dengan Sistem Budidaya Hidroponik NFT. Jurnal Agro. Vol 6(2).

Neli, K. D. 2017. Respon Tanaman Stoberi (Fragaria Sp.) Terhadap berbagai Campuran dan Volume Media Tanaman pada Budidaya di Dataran Rendah. [Skripsi]. Universitas Mataram. Mataram.

Nugraha, A. 2018. Pemanfaatan Media Tanam Hidroponik sebagai Media Tanam Greenroof. [Skripsi]. IPB. Bogor.

Nugraha, R., U., 2014. Sumber Hara Sebagai Pengganti AB Mix pada Budidaya Sayuran Daun secara Hidroponik. [Skripsi]. Institut Pertanian Bogor: Bogor.

Ohorella, D. 2012. Pengaruh Pupuk Majemuk NPK terhadap Pertumbuhan, Produksi, serta Serapan Hara Jagung (Zea mays L.) pada Latosol Darmaga. [Skripsi]. IPB. Bogor.

Palin, M. 2008. Uji Efektivitas Kombinasi Pupuk Growmore 20-20-20 dengan pupuk Kadar $P$ Tinggi untuk memicu Pertumbuhan dengan Pembungaan Adenium. [Skripsi]. IPB..Bogor.

Perwtasari, B., Mustika, T., Catur, W. 2015. Pengaruh Media Tanam dan Nutrisi terhadap Pertumbuhan dan Hasil Tanaman Pakchoy (Brassica juncai L.) dengan Sistem Hidroponik. Jurnal Agrovigor. Vol 5(1).

Raihan, M.A. 2017. Pertumbuhan dan Perkembangan Pakchoy (Brassica chinensis L.) pada berbagai Konsentrasi Pupuk ABmix dan Pupuk Organik Cair (POC) dengan Teknik Hidroponik. [Skripsi]. Universitas Hasanuddin: Makasar.

Riyanti, Y. 2009 Pengaruh Jenis Media Tanam terhadap Pertumbuhan Bibit Sirih Merah (Piper crocatum Ruiz dan pav). [Skripsi]. Institut Pertanian Bogor. Bogor.

Setyawan, A., Medha, B., Lilik, S. 2018. Pengaruh Volume Kompos pada Media Tanaman terhadap Pertumbuhan dan Hasil Tanaman Kangkung (Ipomea reptans poir.) dalam Sistem Vertikultur. Jurnal Produksi Tanaman. Vol 6(7).

Samanhudi dan D. Harjoko. 2010. Pengaturan Komposisi Nutrisi dan Media dalam Budidaya Tanaman Tomat dengan Sistem Hidroponik. J. Ilmiah Pertanian Biofarm. 13 (9) : 1-10.

Safriani, H. 2018. Pengaruh Media Tanam Terhadap Pertumbuhan Tomat sebagai Penunjang Praktikum Fisiologi Tumbuhan. [Skripsi]. Universitas Islam negeri Ar Raniry: Banda Aceh.

Silvina, F. dan Syafrinal. 2008. Penggunaan Berbagai Medium Tanam dan Konsentrasi Pupuk Organik Cair pada Pertumbuhan dan Produksi Mentimun Jepang (Cucumis sativus) secara Hidroponik. J. SAGU. 7 (1) : 7-12.

Siregar, M. 2017. Respon Pemberian Nutrisi AB-Mix pada Sistem Tanam Hidroponik terhadap Pertumbuhan dan Produksi Tanaman Sawi (Brasica juncea). Jurnal of Animal Science andAgronomy Panca Bumi, Vol 2(2). 
Syariefa, Duryatmo, Angkasa. 2014. Hidroponik Praktis. Jakarta: PT Trubus Swadaya.

Sutiyoso, Y. 2006. Meramu Pupuk Hidroponik. Penebar Swadaya. Jakarta.

Sundari., Ince, R., Untung, S. H. 2016. Pengaruh POC dan $A B$ Mix terhadap Pertumbuhan dan Hasil Tanaman Pakchoy (Brassica chinensis L.) dengan Sistem Hidroponik. Jurnal Magrobis. Vol 16(2).

Trikorianto, A. 2018. Uji Berbagai Tanaman dan Pemberian Nutrisi terhadap Pertumbuhan Tanaman Selada (Lactuca sativa L.) dengan system Hidroponik. Jurnal Agrohita. Vol xviii (1).
Tripama, H., Rizal, H. 2018. Interaksi Sistem Pertanaman Hidroponik dengan Pemberian Nutrisi $A B$ Mix terhadap Pertumbuhan dan Produksi sawi. Jurnal Agrohita. Vol 2(2).

Wijayanti, E. 2012. Pengaruh Komposisi Media Tanam terhadap Pertumbuhan dan Produksi dua Varietas tomat secara Hidroponik. [Skripsi]. Institut Pertanian Bogor. Bogor

Warman., Syawaluddin., Imelda, S. 2016. Pengaruh Perbandingan Produksi Larutan Hidroponik dan Media Tanam terhadap Pertumbuhan serta Hasil Produksi Tanaman sawi. Jurnal Agrohita. Vol 1(1). 